\title{
Deposition, burial and sequestration of carbon in an oligotrophic, tropical lake
}

\author{
Javier ALCOCER, ${ }^{1 *}$ Ana C. RUIZ-FERNÁNDEZ, ${ }^{2}$ Elva ESCOBAR,${ }^{3}$ Libia H. PÉREZ-BERNAL, ${ }^{2}$ Luis A. OSEGUERA, ${ }^{1}$ \\ Vilma ARDILES-GLORIA ${ }^{1}$
}

${ }^{1}$ Universidad Nacional Autónoma de México, Facultad de Estudios Superiores Iztacala, Proyecto de Investigación en Limnología Tropical, Av. de los Barrios No. 1, Los Reyes Iztacala, 54090 Tlalnepantla, Estado de México; ${ }^{2}$ Universidad Nacional Autónoma de México, Instituto de Ciencias del Mar y Limnología, Unidad Académica Mazatlán, Calz. Montes Camarena s/n, 82040 Mazatlán, Sin; ${ }^{3}$ Universidad Nacional Autónoma de México, Instituto de Ciencias del Mar y Limnología, Ecología Marina y Biodiversidad, Laboratorio de Biodiversidad y Macroecología, Ciudad Universitaria A.P. 70-305, 04510 México, D.F., México

*Corresponding author: jalcocer@unam.mx

\begin{abstract}
The amount of biogenic carbon that may be deposited, buried and eventually preserved (sequestered) in the sediments of a tropical, oligotrophic lake, was evaluated based on i) the temporal variation of the particulate organic carbon (POC) concentration in the superficial sediments in the deep zone of Lake Alchichica, Puebla, Mexico; and ii) the POC accumulation and preservation in a ${ }^{210} \mathrm{~Pb}$-dated sediment core from the lake. In Lake Alchichica the POC concentration in the surficial sediments ranged between 12 and $60 \mathrm{mg} \mathrm{POC}^{-1}\left(25 \pm 12 \mathrm{mg}\right.$ POC $\mathrm{g}^{-1}$ dry weight). The magnitude of the sedimented POC in Alchichica was high and mostly of autochthonous origin. The POC concentrations recorded in the sediment core (16.6 to $31.6 \mathrm{mg} \mathrm{g}^{-1}$ dry weight) were comparable to the concentration range observed in the surface sediment samples collected during the study period, which signaled a high POC preservation capacity in the sedimentary column of Lake Alchichica. The POC fluxes, estimated from the ${ }^{210} \mathrm{~Pb}$-dated sediment core, varied between 14.9 and $35.3 \mathrm{~g} \mathrm{~m}^{-2} \mathrm{year}^{-1}$ within the past century; and the maximum POC losses through diagenesis during this period were estimated to be lower than 25\%. This study concludes that deep tropical lakes, exemplified by Lake Alchichica, accumulate and preserve most of the POC deposited, playing an important role in regional carbon balances.
\end{abstract}

Key words: Alchichica, biogenic carbon, POC, chlorophyll a, tropical lake, Mexico.

Received: April 2013. Accepted: October 2013.

\section{INTRODUCTION}

Phytoplankton either aggregate and sink or are consumed by the heterotrophs, transferring organic carbon (OC) through the food web. One portion of the fixed OC is oxidized within the euphotic zone and returned to the atmosphere; on the other hand, the $\mathrm{OC}$ not consumed in the euphotic zone will be eventually exported below the thermocline and transported to the sediment as dead organisms, fecal pellets or macroscopic aggregates $(>500$ $\mu \mathrm{m})$ composed of organic and inorganic detritus commonly known as marine or lake snow (Honjo et al., 1982; Billett et al., 1983; Simon et al., 2002). In addition to their own primary production (PP), most lakes are sustained by allochthonous $\mathrm{OC}$ from the watershed; as a consequence, respiration (R) dominates over PP (Del Giorgio and Peters, 1993; Jansson et al., 2000; Duarte and Prairie 2005; all cited in Cole et al., 2007). The particulate organic carbon (POC) flux reaching the sediments is controlled by the aggregation and disaggregation of organic compounds, microbial activity, zooplankton grazing and production of faecal pellets, and the interaction between the aggregates and the mineral ballast and dust (De La Rocha and Passow, 2007). POC burial in sediments can be thought of in terms of the balance between PP and R on land and in the oceans; and in this way, the burial of organic matter (OM) in sediments leads to net $\mathrm{CO}_{2}$ removal from (and oxygen input to) the atmosphere (Burdige, 2007). On the other hand, as mentioned above, lakes receive large amounts of $\mathrm{OC}$ from the watershed, and then these are net heterotrophic in nature, emitting large quantities of $\mathrm{CO}_{2}$ while, at the same time, storing and sequestering considerable amounts of carbon (C) received from the terrestrial environment (Tranvik et al., 2009). Almost half of the phytoplankton production in aquatic environments is transferred to the bottom layers of the water column by sedimentation (Bloesch and Uehlinger, 1990). The fate of POC in aquatic ecosystems can be predicted by the size of the dominant phytoplankton (Legendre, 1999). If small phytoplankton dominates, the POC composition will lead to $\mathrm{C}$ recycling in the euphotic zone through the microbial loop; if large phytoplankton dominates, the POC composition will be aggregated and exported to the sediment.

Most studies on POC fluxes concern the oceanic contribution to the biogeochemistry of atmosphere-ocean $\mathrm{C}$ fluxes, the inorganic to organic $\mathrm{C}$ conversion rates and the POC sedimentation rates (Takahashi et al., 2000). Fewer studies deal with inland waters, and most of these have 
been carried out in temperate lakes (Callieri et al., 1986; Punning et al., 2003) and fewer in tropical locations (Pilskaln, 2004). Most epicontinental aquatic systems are small $\left(0.012 \mathrm{~km}^{2}\right.$ on average), shallow and eutrophic, but are important places for processing $\mathrm{C}$ and can influence local and regional C balances (Cole et al., 2007; Tranvik et al., 2009). In Mexican lakes, Alcocer et al. (2007) studied the seasonal variation of POC in the water column of oligotrophic Lake Alchichica, Mexico, and reported that the concentration of the sestonic organic fraction varied during the year from $<0.1$ to $4.0 \mathrm{mg} \mathrm{L}^{-1}$, with an average of $1.0 \pm 0.7 \mathrm{mg} \mathrm{L}^{-1}$. This range is similar to those found in other oligotrophic and even mesotrophic lakes such as Lake Maggiore in Italy (Bertoni and Callieri, 1981; Callieri, 1997) and Lake Dudinghausen in Germany (Selig et al., 2006). Oseguera et al. (2010) recognized a correlation between the dynamics of chlorophyll $a(\mathrm{Chl} a)$ and the seston fluxes and concluded that Chl $a$ is a good proxy for POC in Lake Alchichica. The dominant size of the phytoplankton has been related to the trophic status of lakes (Lampert and Sommer, 1997). Small phytoplankton characterizes oligotrophic lakes, whereas large phytoplankton is more common in eutrophic systems. In spite of its oligotrophic status, Lake Alchichica is dominated by large ( $>2$ $\mu \mathrm{m})$ phytoplankton (Adame et al., 2008) and, according to Legendre's model (1999), this suggests that most of the phytoplankton would be preferentially exported, yielding POC fluxes higher than expected for lakes of similar trophic status. Tropical, deep maar lakes like Alchichica seem to be underrepresented in the Tranvik et al. (2009) paper (where tropical lakes are illustrated by an Amazon floodplain lake). Alchichica corresponds to the basic type, one of the five tropical lake-types mentioned by Lewis (2010). This is a common tropical lake with numerous examples in Mexico along the Trans-Mexican Volcanic Belt [Santa María del Oro in Nayarit, Los Espinos in Michoacán, Atexcac in Puebla and Majahual in Veracruz (Alcocer and Bernal-Brooks, 2010)], and elsewhere.

This study identifies the role of deep, oligotrophic and tropical inland aquatic ecosystems in POC deposition, burial and sequestration, and their relevance to the global $\mathrm{C}$ cycle and to the regional $\mathrm{C}$ balances by evaluating: i) the temporal variation of the biogenic POC concentration in the surface layers of sediments of Lake Alchichica, Puebla, Mexico; and ii) the POC accumulation and preservation in $\mathrm{a}^{210} \mathrm{~Pb}$ dated-sediment core from the lake.

\section{METHODS}

\section{Study area}

Alchichica is a maar lake in the endorheic Oriental Basin, Central Mexico, at $19^{\circ} 24^{\prime} \mathrm{N}, 97^{\circ} 24^{\prime} \mathrm{W}$ and 2345 $\mathrm{m}$ asl. The area displays a monsoon-type climate with two main seasons throughout the year: i) a cold and dry season from January to March, characterized by the lowest ambient temperature $\left(\approx 9^{\circ} \mathrm{C}\right)$, and a monthly precipitation less than $26 \mathrm{~mm}$; and ii) a warm, rainy season from April to December, with an average ambient temperature of $16^{\circ} \mathrm{C}$ and a total precipitation of $301 \mathrm{~mm}$ (Oseguera et al., 2011). Large agricultural areas surround the lake.

Alchichica is one of the deepest lakes in Mexico, with maximum and mean depths of 62 and $41 \mathrm{~m}$, respectively, and a surface area of $2.3 \mathrm{~km}^{2}$. Its basin holds $94,214,080$ $\mathrm{m}^{3}$ of saline (total dissolved solids $7.2 \pm 0.1 \mathrm{~g} \mathrm{~L}^{-1}$ ) and alkaline ( $\mathrm{pH}$ 8.7-9.2) water, dominated by sodium and chloride ions (Vilaclara et al., 1993; Filonov et al., 2006). Since the lake is groundwater-fed with no surface inflows, Alchichica receives no run-off $\mathrm{POC}$ and almost no aerial dustfall POC (24-36 $\mathrm{m} \mathrm{m}^{-2} \mathrm{~d}^{-1}$ ) from the watershed (Oseguera et al., 2011). Alchichica is a warm monomictic lake characterized by a brief circulation (turnover) period that occurs during the cold, dry season (January-March), and a long stratification period that takes place during the warm, rainy season. There are three periods during the stratification: early (April-June), well-established (JulySeptember) and late (October-December) stratification (Alcocer et al., 2000). During the stratification phase, the mixed layer depth $\left(\mathrm{Z}_{\mathrm{MIX}}\right)$ ranges between 10 and $34 \mathrm{~m}$ and a clear-water phase occurs, in which the euphotic zone $\left(\mathrm{Z}_{\mathrm{EU}}\right)$ may extend down as far as $38 \mathrm{~m}$, closely coupled with the thermocline (Adame et al., 2008) and reaching the middle or the bottom of the metalimnion. During the circulation period, the water column becomes turbid and $\mathrm{Z}_{\mathrm{EU}}$ decreases to $13-17 \mathrm{~m}$.

Lake Alchichica is oligotrophic, with annual mean Chl $a$ concentrations $<5 \mu \mathrm{g} \mathrm{L}^{-1}$ (Alcocer et al., 2000). There are three main events in phytoplankton development during the annual cycle (Lugo et al., 2000; Oliva et al., 2001): i) a full water column diatom bloom dominated by $C y$ clotella alchichicana (35-63 $\mu \mathrm{m}$ diameter, Oliva et al., 2006) and C. choctawhatcheeana (5-12 $\mu \mathrm{m}$ diameter, Oliva et al., 2008) that takes place during the winter circulation; ii) a spring bloom of the nitrogen-fixing cyanobacterium Nodularia spumigena $(>100 \mu \mathrm{m})$ in the early stratification period; and iii) a deep chlorophyll maximum (DCM) that appears in the metalimnion from the period of well-established stratification to the period of late stratification (September-November) and that is composed once again of Cyclotella spp.

Reported overall concentrations of total N $(4.14 \pm 0.69$ $\mu \mathrm{M})$ and total $\mathrm{P}(0.21 \pm 0.04 \mu \mathrm{M})$ are typically low in the mixed layer (Oliva et al., 2001; RamosHiguera et al., 2008) and show spatiotemporal dynamics related to the lake's thermal regime: a marked epilimnetic depletion and hypolimnetic accumulation during the stratification period, and a high concentration of nutrients homogeneously distributed throughout the water column as circulation takes place. 


\section{Sampling}

We evaluated: i) the lake hydrodynamics through measuring temperature and dissolved oxygen profiles; ii) the POC deposition dynamics through the analysis of the Chl $a$ concentration in the superficial sediments of the deep zone; and iii) the POC fluxes, and preservation through the analysis of POC concentration within a ${ }^{210} \mathrm{~Pb}$ dated sediment core. The thermal behaviour of the lake during five years (2003-2007) was identified by measuring water column temperature and dissolved oxygen profiles monthly in the central and deepest part of the lake. The temporal variation of the biogenic carbon (POC) concentration in the surface layers of the deep sediments was measured at the same sampling station on the same sampling dates during the same period by evaluating the sedimentary $\mathrm{Chl} a$ concentration. To analyze the POC accumulation and preservation, a sediment core was collected at $19^{\circ} 24.473^{\prime} \mathrm{N}, 97^{\circ} 24.096^{\prime} \mathrm{W}$ on 22 November 2005 at $60 \mathrm{~m}$ depth. Profiles of temperature and dissolved oxygen were measured in situ with a water quality sonde (Hydrolab DS-4/SVR-4). Surface sediments were collected with an Ekman dredge $\left(0.0225 \mathrm{~m}^{2}\right)$ from which two sediment aliquots $\left(1 \mathrm{~cm}^{3}\right)$ were obtained with a manual corer $(\mathrm{L}=10, \varnothing=1 \mathrm{~cm})$, taking care not to disturb the surficial layer. The sediment subsamples were kept frozen in dark centrifuge tubes until analysis. Pigments were extracted from the surficial sediment by shaking with $90 \%$ acetone at $4^{\circ} \mathrm{C}$ overnight. Samples were then centrifuged (15 min, $675 \mathrm{~g}$ ) and the supernatant was analyzed with a 10-AU fluorometer (EPA method 445.0, Arar and Collins, 1997), which was calibrated annually with pure $\mathrm{Chl} a$, and during each field trip with a solid secondary standard (Turner Designs).

We estimated surficial sediment POC from sedimentary chlorophyll $a$ concentration, which represents the phototrophic carbon reaching the surficial sediments. This calculation does not consider other sources of carbon (e.g., zooplankton) to the sediments so our values should be considered as the minimum POC concentration exported to the sediments. However, a recent sediment-trap study on Lake Alchichica (Oseguera et al., 2011) showed that most ( $>90 \%)$ POC reaching the deep sediments is of phytoplanktonic origin, so our estimates must be quite close to the actual POC values. Chl $a$ is commonly used to estimate phytoplankton biomass (Chang et al., 2003). POC was estimated through the POC:Chl $a$ ratio (Cho and Azam, 1990) in the surficial sediments. In the present study we used four POC:Chl $a$ ratios (one ratio for each one of the four hydrodynamic periods of the lake), with the following values based on Velasco et al. (2011) and Oseguera et al. (2010): 119 for the circulation phase (January to March); 215 during the period of early stratification (April to June), 112 during the period of well-established stratification (July to September), and 83 during the late stratification period (October to December). The carbon concentrations, originally calculated as $\mathrm{mg} \mathrm{C} \mathrm{cm}{ }^{-3}$ of surficial sediment, were transformed to $\mathrm{mg}$ $\mathrm{C}$ per gram of dry sediment using the following equation:

$$
\begin{gathered}
\mathrm{mg} \mathrm{C} \mathrm{g}^{-1} \text { sediment }=\left(\mathrm{mg} \mathrm{C} \mathrm{cm}^{-3}\right) / \\
{[(1 \text { - porosity }) \mathrm{x}(\text { sediment density })]}
\end{gathered}
$$

Porosity was assumed to lie within a range of $74-88 \%$ and the density within a range of $1.2-1.5 \mathrm{~g} \mathrm{~cm}^{-3}$ on a wetweight basis. These values were obtained from the literature (Koegler, 1967) for sediments characterized by values within the range of $2.5-6.5 \%$ organic carbon and 3-6\% carbonate content. The sediment core was collected with a UWITEC ${ }^{\text {TM }}$ gravity corer $(9 \mathrm{~cm}$ inner diameter) in November 2005. No evidence of sediment disturbance (sediment cracks, gas bubbles, infaunal burrows) was seen. The sediment core was extruded and subsampled at $1-\mathrm{cm}$ intervals (with the exception of the two uppermost layers, which were each $1.5 \mathrm{~cm}$ thick). The sediments were freeze-dried and ground with a mortar and pestle for further analysis. The POC content of the sediment core was estimated by the Walkey-Black method (Loring and Rantala, 1992), in which an aliquot of $0.5 \mathrm{~g}$ of dry sediments was treated with $10 \mathrm{ml}$ of a mixture of $\mathrm{K}_{2} \mathrm{Cr}_{2} \mathrm{O}_{7}+\mathrm{Ag}_{2} \mathrm{SO}_{4}+\mathrm{H}_{2} \mathrm{SO}_{4}$ to oxidize the organic matter present in the sample. The oxidant mixture that was not consumed was back-titrated with $\mathrm{Fe}\left(\mathrm{NH}_{4}\right)_{2}\left(\mathrm{SO}_{4}\right)_{2}$ (El Rayis, 1985). Concentrations are reported as percentages on a dry weight basis (d.w.). Replicates of the sediment sample analyses $(n=6)$ yielded a variation coefficient of $4 \% .{ }^{210} \mathrm{~Pb}$ activities for sediment core dating were obtained by measuring the derived ${ }^{210} \mathrm{Po}$ daughter products, assuming secular equilibrium between the two isotopes (Schell and Nevissi, 1983; SánchezCabeza et al., 1998). Sediment aliquots (0.3 g) were spiked with ${ }^{209} \mathrm{Po}$ as yield tracer, and digested in Savillex ${ }^{\mathrm{TM}}$ PFA containers, in a 5:4:1 mixture of $\mathrm{HNO}_{3}+\mathrm{HCl}+\mathrm{HF}$ on a hotplate $\left(150-180^{\circ} \mathrm{C}\right)$ overnight. The residue was converted to a chloride salt by repeated evaporation with $12 \mathrm{M} \mathrm{HCl}$, then dissolved in $0.5 \mathrm{M} \mathrm{HCl}$ with $2.5 \mathrm{~g}^{\circ} \mathrm{H}_{3} \mathrm{BO}_{4}$, and $0.2 \mathrm{~g}$ of ascorbic acid were added to the solution. Po isotopes were deposited on a spinning Ag disc (Hamilton and Smith, $1986)$ and the activity measured by $\alpha$-spectrometry using ORTEC silicon surface barrier detectors coupled to a PC running under Maestro ${ }^{\mathrm{TM}}$ data acquisition software. Blanks were run in parallel to correct for any contamination. Accuracy and precision of the ${ }^{210} \mathrm{Po}$ method were determined through replicate analyses of the standard reference material IAEA-300 and were determined to be $99 \%$ and $4.6 \%$, respectively. The uncertainty in the ${ }^{210} \mathrm{~Pb}$ data, estimated through quadratic uncertainty propagation, was less than $5 \%$ in all cases. The ${ }^{210} \mathrm{~Pb}$ chronology for the Alchichica core was constructed with the Constant Flux-CF model (Robbins, 1978; Sánchez-Cabeza and Ruiz-Fernández, 
2012), which assumes a constant rate of supply of fallout ${ }^{210} \mathrm{~Pb}$ irrespective of any changes in the sedimentation rate. ${ }^{210} \mathrm{~Pb}$ data are reported on a dry weight basis.

The simple rate model for organic decomposition proposed by Middelburg (1989) was used to model POC concentration in time, assuming constant input and the steady-state diagenetic process during the period represented by the ${ }^{210} \mathrm{~Pb}$-derived chronology based on the following equation:

$$
G_{t}=G_{o} e^{-\left(3.2 t^{0.05)}\right.}
$$

where $G_{t}$ is the metabolizable organic component of POC deposited at time $t$, and $\mathrm{G}_{\mathrm{o}}$ represents the degradable element concentration at the sediment surface, which was chosen to provide general correspondence between the model and the measured non-metabolizable POC concentrations (the vertical asymptote of the POC profile).

The additional POC concentration not attributable to steady-state degradation is defined as excess POC. The fluxes of excess POC to the sediments were estimated based on POC concentrations corrected for the degradative loss that occurred with time. This approach allows the role of diagenesis on the POC sedimentary record to be taken into account in order to distinguish whether the system is at steady state or has been affected by environmental changes (e.g., changes in mass sedimentation rates or increased delivery of POC to the sediments). The POC lost to degradation for any sample deposited t years ago $\left(\mathrm{C}_{\text {lost- } \mathrm{t}}\right)$ was estimated as in Zimmerman and Canuel (2002):

$$
\mathrm{C}_{\text {lost-t }}=\mathrm{C}_{\mathrm{m}(\mathrm{o})}-\mathrm{C}_{\mathrm{M}}
$$

where $\mathrm{C}_{\mathrm{m}(\mathrm{o})}$ is the initial POC concentration measured in the surface layer of the core, and $\mathrm{C}_{\mathrm{M}}$ denotes the POC concentrations derived by the Middelburg model for each layer of the core, representing the POC content that should be accumulated in the sediment core under steady state conditions.

The degradation-corrected concentration $\left(\mathrm{C}_{\text {corr- } t}\right)$ for a sample of concentration $\mathrm{C}_{\mathrm{mt}}$ is expressed as:

$$
\mathrm{C}_{\text {corr-t }}=\mathrm{C}_{\mathrm{mt}}+\mathrm{C}_{\text {lost-t }}
$$

where $\mathrm{C}_{\mathrm{mt}}$ represents the metabolizable organic content at time t.

\section{RESULTS}

\section{Lake hydrodynamics}

Lake hydrodynamics were similar across the five years (Fig. 1), displaying the warm monomixis pattern

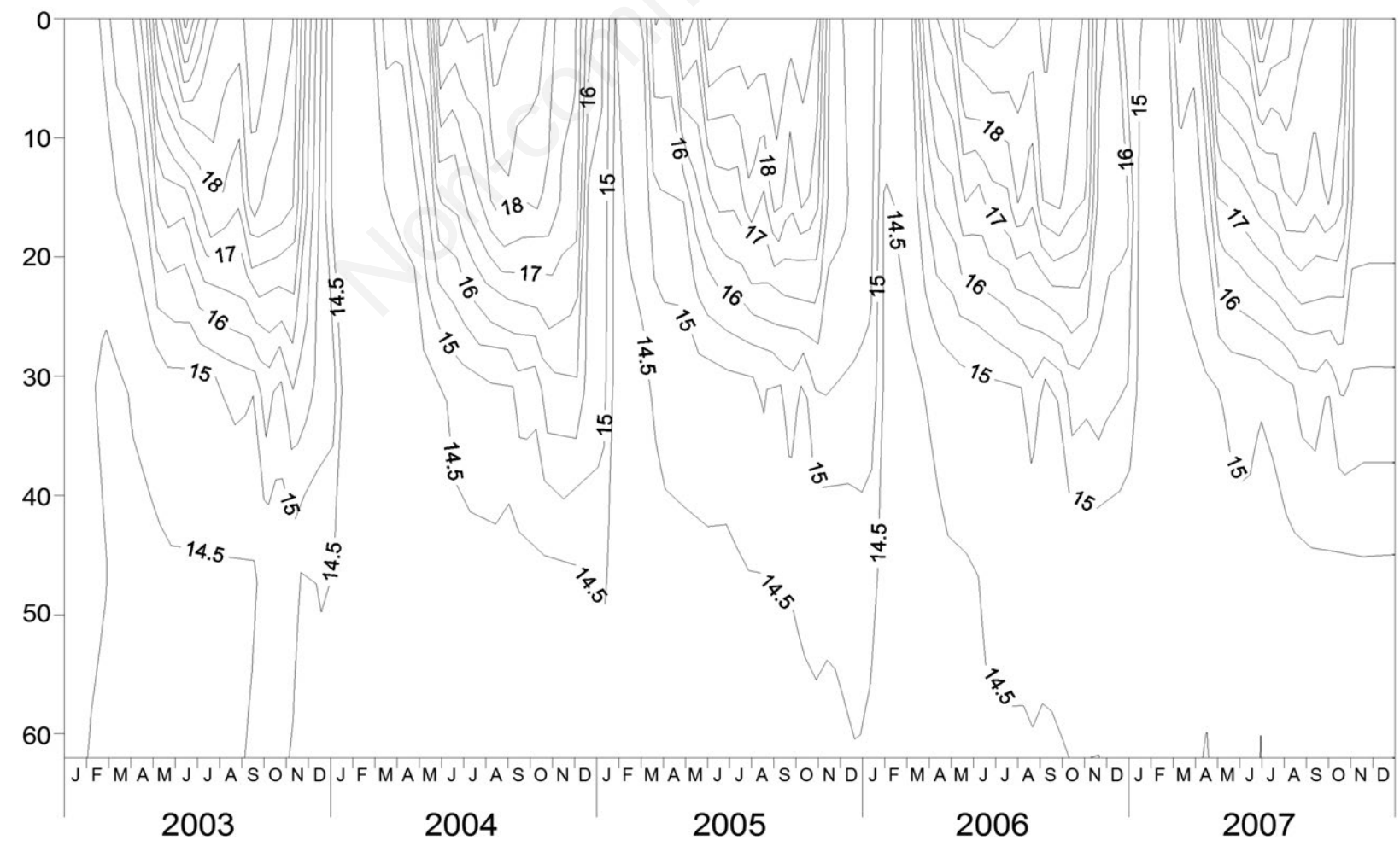

Fig. 1. Depth-time diagram of isotherms $\left({ }^{\circ} \mathrm{C}\right)$ in Lake Alchichica. 
previously described by Alcocer et al. (2000). The lake mixes in winter when the epilimnion temperature drops to $14.5 \pm 0.3^{\circ} \mathrm{C}$. As the lake stratifies, the epilimnetic water warms in spring $\left(17.8 \pm 1.5^{\circ} \mathrm{C}\right)$, reaching its highest temperature in summer $\left(18.7 \pm 1.5^{\circ} \mathrm{C}\right)$, and cools again in autumn $\left(16.7 \pm 1.6^{\circ} \mathrm{C}\right)$. Hypolimnetic temperature was homogeneous through the stratification season with an average of $14.5 \pm 0.2^{\circ} \mathrm{C}$. There were no significant (one-way ANOVA test; $\mathrm{P}>0.05$ ) interannual differences in water temperatures during the period of study (2003-2007).

The dissolved oxygen (DO) concentration (Fig. 2) was low $\left(3.7 \pm 1.5 \mathrm{mg} \mathrm{L}^{-1} ; 51 \pm 21 \%\right.$ saturation) at the beginning of the circulation period as a result of the mixture of the well-oxygenated epilimnetic with the anoxic hypolimnetic waters. Throughout the circulation period the DO concentration was $5.3 \pm 1.0 \mathrm{mg} \mathrm{L}^{-1}(72 \pm 14 \%$ saturation). Epilimnetic DO concentrations were high $\left(6.3 \pm 0.8 \mathrm{mg} \mathrm{L}^{-1}\right)$, close to saturation $(91 \pm 14 \%)$. Hypolimnetic DO concentrations fell as soon as the lake stratified and reached total anoxia from July to December, as previously observed by Alcocer et al. (2008). Tropical warm monomictic lakes commonly display an anoxic hypolimnion; the warmer hypolimnetic waters have DO concentrations lower than those in temperate lakes, leading to a rapid development of anoxic conditions (Lewis, 2002). No significant (one- way ANOVA test; $\mathrm{P}>0.05$ ) interannual differences were observed for the DO content in the water column during the study (2003-2007).

\section{Particulate organic carbon deposition}

The Chl $a$ extracted from the surface sediments in Lake Alchichica derives mostly from the sedimentation of the diatom Cyclotella alchichicana $(\geq 35 \mu \mathrm{m})$ that represents up to $98 \%$ of the total phytoplankton biomass being exported below the thermocline (Ardiles et al., 2011). The estimated POC concentration in the surficial sediment ranged between 12 and $60 \mathrm{mg} P O C \mathrm{~g}^{-1}$ d.w. (Fig. 3) with an average value of $25 \pm 12 \mathrm{mg} \mathrm{POC} \mathrm{g}^{-1}$ d.w. $(\mathrm{n}=116)$; the annual average concentrations are shown in Tab. 1. There were no significant interannual (2003-2007) differences (one-way ANOVA test; $\mathrm{P}>0.05$ ) in estimated POC concentrations in the sediments; however, the estimated POC concentration in the early stratification phase was significantly higher (one-way ANOVA test; $\mathrm{P}<0.05$ ) than the estimated POC concentrations in the other phases. The POC accumulates during the early stratification period as a result of the sinking diatoms produced in the bloom that takes place during the mixing phase (Fig. 3). Oseguera et al. (2011) found a similar seasonal pattern of the total

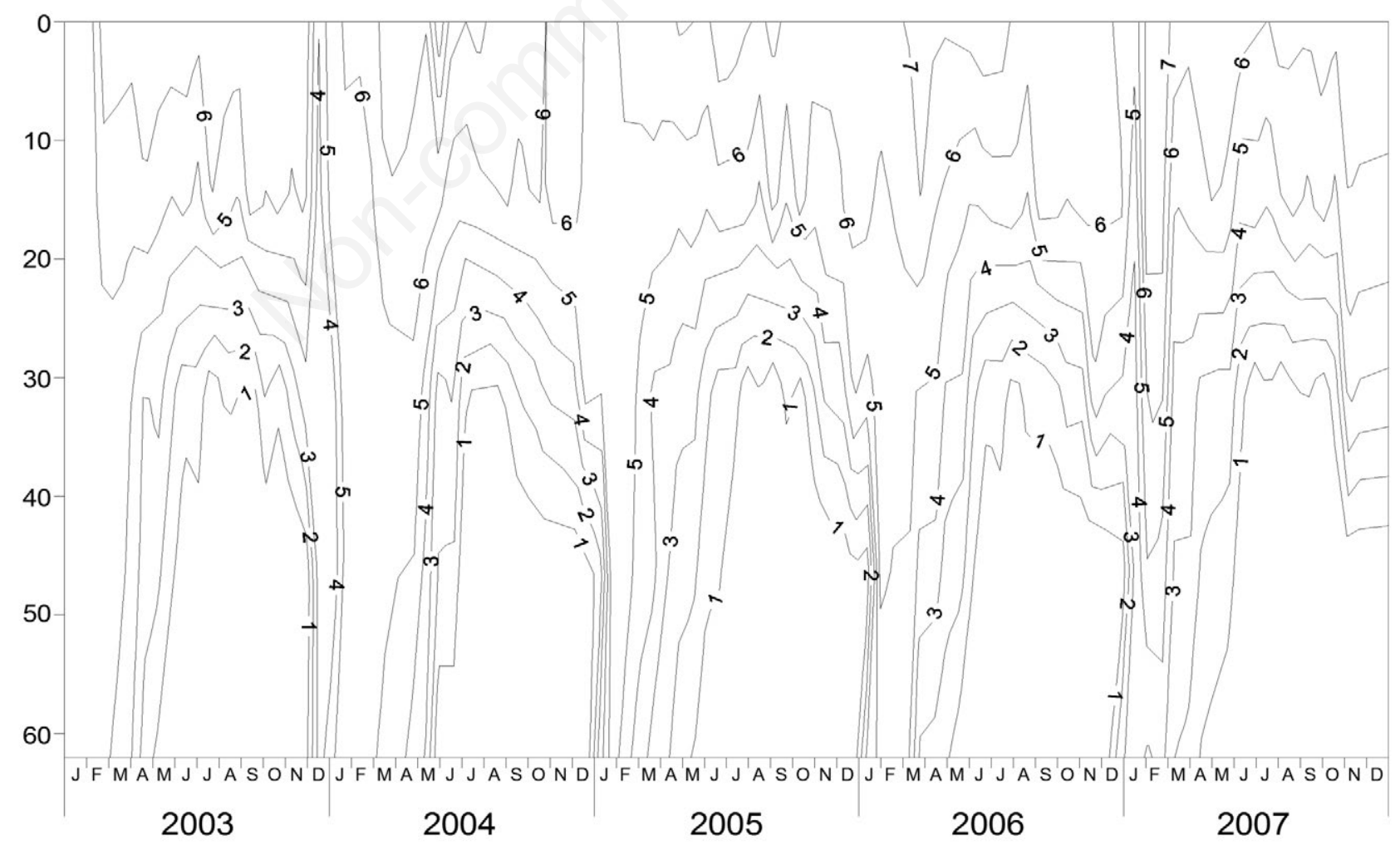

Fig. 2. Depth-time diagram of isopleths of dissolved oxygen $\left(\mathrm{mg} \mathrm{L}^{-1}\right)$ in Lake Alchichica. 
particulate matter flux in this lake, with higher fluxes related to the end of the diatom bloom.

\section{Radioisotope dating}

The sedimentation rates in the Alchichica sediment core were estimated from the radioactive disequilibrium of ${ }^{210} \mathrm{~Pb}$. Total ${ }^{210} \mathrm{~Pb}$ activities $\left({ }^{210} \mathrm{~Pb}_{\text {tot }}\right)$ ranged from $3.72 \pm 0.11$ to $89.07 \pm 2.67 \mathrm{~Bq} \mathrm{~kg}{ }^{-1}$; supported ${ }^{210} \mathrm{~Pb}$ $\left({ }^{210} \mathrm{~Pb}_{\text {sup }}\right)$ was calculated as the average ${ }^{210} \mathrm{~Pb}_{\text {tot }}$ concentrations between 54 and $62 \mathrm{~cm}$ depth $\left(4.65 \pm 0.42 \mathrm{~Bq} \mathrm{~kg}^{-1}\right)$ and the excess ${ }^{210} \mathrm{~Pb}$ activities $\left({ }^{210} \mathrm{~Pb}_{\text {exc }}\right)$ were calculated as the difference between ${ }^{210} \mathrm{~Pb}_{\text {tot }}$ and ${ }^{210} \mathrm{~Pb}_{\text {sup }}$. The ${ }^{210} \mathrm{~Pb}_{\text {exc }}$ activities decreased with depth. A slight departure from the typical exponential decay curve was recorded between the surface and $12 \mathrm{~cm}$ depth (Fig. 4a), suggesting that accretion may not have been constant through time.

The Alchichica sediment record provided a geochronology of $104.2 \pm 6.8$ years up to $35 \mathrm{~cm}$ depth. The sediment accumulation rate (SAR) varied along the core from 0.16 to $0.39 \mathrm{~cm}$ year $^{-1}$, and the mass accumulation rate (MAR) from 0.06 to $0.11 \mathrm{~g} \mathrm{~cm}^{-2}$ year $^{-1}$; and both SAR and MAR showed a decreasing trend from $14 \mathrm{~cm}$ depth upwards (i.e., 1969, Fig. 4b).

\section{Core particulate organic carbon content and fluxes}

The POC concentrations in the sediment core ranged from 16.6 to $31.6 \mathrm{mg} \mathrm{g}^{-1}$. The POC sediment concentration profile displayed important deviations from the typical exponential decay trend (organic carbon diagenetic profiles) above $12 \mathrm{~cm}$ depth and below $40 \mathrm{~cm}$ depth (Fig. 5). This pattern might result from variations in sediment texture or sediment bulk density due to compaction; however the sediments in the Alchichica were clayey (grain size was homogenous along the core) and therefore the variations in POC concentration are unrelated to changes in grainsize distribution. The POC concentrations were also plotted as a function of the cumulative weight of the sediment $\left(\mathrm{g} \mathrm{cm}^{-2}\right.$, Fig. 5) with the purpose of removing the compaction effect on the sediment (Robbins, 1978). The resulting profile produced the same pattern as that

Tab. 1. Particulate organic carbon concentration in the surficial sediments of the deep region of Lake Alchichica.

\begin{tabular}{lcccc}
\hline \multicolumn{5}{c}{$\begin{array}{c}\text { POC concentration } \\
\left(\mathrm{mg} \mathrm{POC}^{-1} \text { d.w. of sediment }\right)\end{array}$} \\
\hline Year & Mean & Min & Max & $\mathrm{N}$ \\
\hline 2003 & $22 \pm 10$ & 12 & 44 & 24 \\
2004 & $25 \pm 14$ & 14 & 60 & 24 \\
2005 & $25 \pm 11$ & 14 & 44 & 22 \\
2006 & $29 \pm 17$ & 12 & 54 & 22 \\
2007 & $24 \pm 11$ & 13 & 51 & 24 \\
\hline
\end{tabular}

POC, particulate organic carbon; d.w., dry weight.

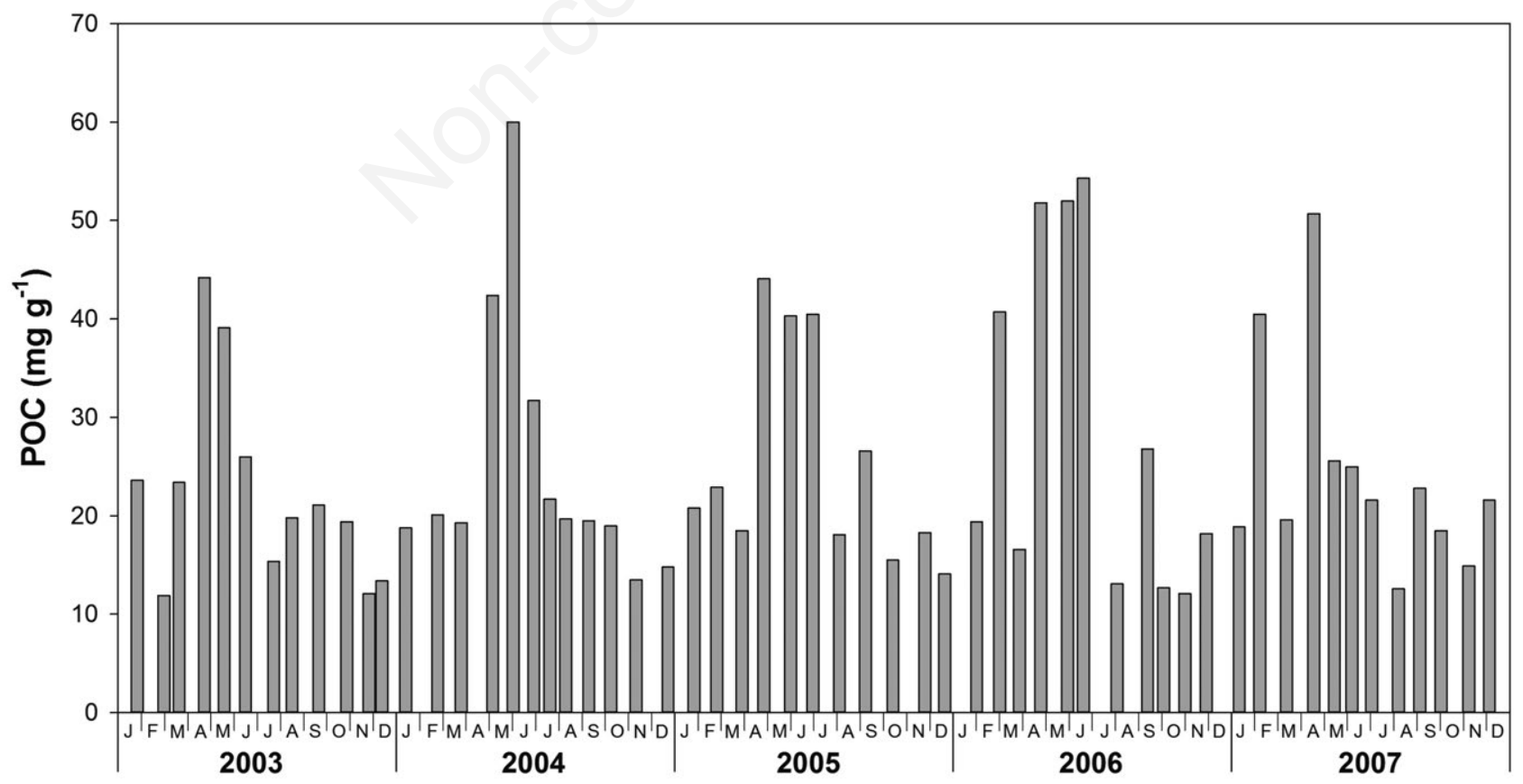

Fig. 3. POC concentration ( $\mathrm{mg} \mathrm{g}^{-1}$ d.w.) in the surficial sediments of the deep region of Lake Alchichica. 
previously described, indicating that the effect of compaction on POC concentration depth profile is negligible. Thus, the changes observed in the POC profile suggest that POC input or degradation might not have been constant with time along the core. The measured and modeled POC concentrations are shown in Tab. 2. Although the Middelburg model partially described the POC concentrations recorded in the core (Fig. 6a), an important deviation of the expected POC concentrations was observed between the surface of the core and $7 \mathrm{~cm}$ depth (from the early 1980s to the most recent years); this suggests a reduction in the POC supply to the system in this segment of the record, indicating that the POC concentrations found cannot be accounted for in terms of steady POC input and a time-dependent decomposition along the entire core. In consequence, this segment of the core was modelled separately from the rest of the POC concentration depth profile. Within the POC concentration depth profile two segments were considered, where significant exponential trends with depth were observed (Student's $t$-test; $\mathrm{P}<0.05$ ): segment $\mathrm{A}$, from the surface to $7 \mathrm{~cm}$ depth, $\mathrm{n}=6, \mathrm{r}=0.86$; and segment $\mathrm{B}$, from 14 to $32 \mathrm{~cm}$ depth, $\mathrm{n}=27, \mathrm{r}=0.83$. The intermediate segment $(7$ to $14 \mathrm{~cm}$ depth) was excluded since it did not conform to any of the trends observed.

The upper part of the sediment core (segment A) is

a

$$
{ }^{210} \mathrm{~Pb}_{\text {exc }}\left(\mathrm{Bq} \mathrm{kg}^{-1}\right)
$$

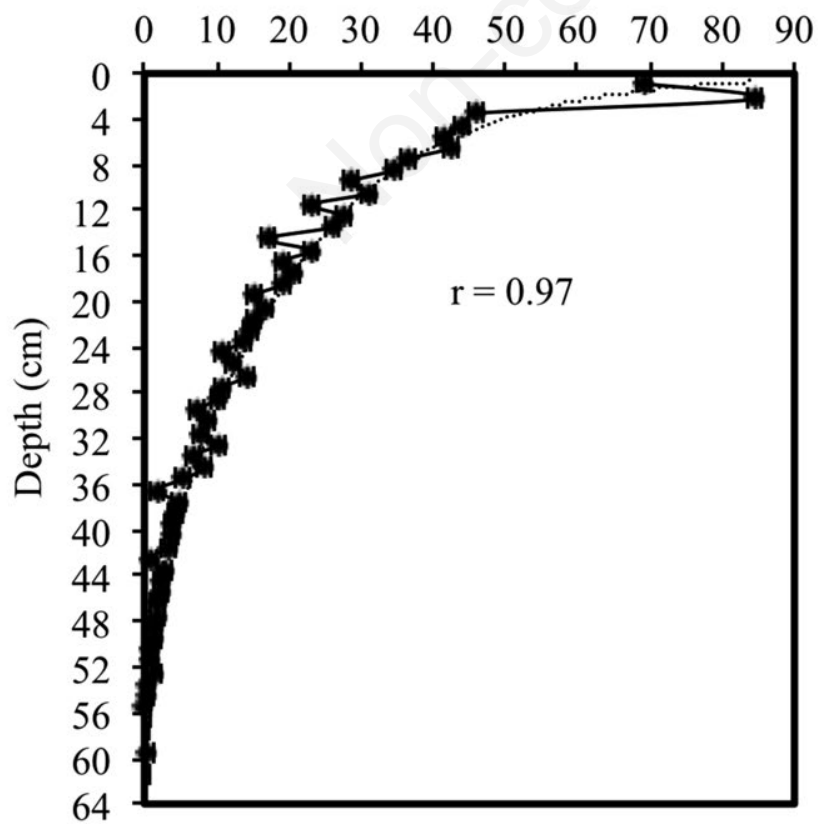

now reasonably well described by the Middelburg model (Fig. 6b), and the differences between the measured and the modeled POC are generally below 3\%, except at the surface layer of the core where the POC concentration is $14 \%$ lower than the predicted value. In the lower part of the core (segment B) the POC concentrations measured in most of the sediment layers (Fig. 6c) are slightly higher than the modeled ones (maximum difference 36\%). The differences between the measured and modeled POC concentrations in segment A suggested that the POC record is mostly the result of diagenetic processes and minor fluctuations in POC deposition. In contrast, section B showed POC in excess of that which can be attributed to steady-state degradation, which might be the result of an increase in the delivery of organic matter to the sediment, or might be attributable to enhanced organic matter preservation due to higher sediment MAR or decreased bottom-water dissolved oxygen concentration. The POC losses through diagenesis (POC measured/POC corrected) were estimated to be $\leq 11 \%$ in segment $A$ and $\leq 25 \%$ in segment $\mathrm{B}$, which means that the sediments have preserved more than $89 \%$ and $75 \%$, respectively, of the POC deposited in each segment.

The modeled fluxes of POC to the sediment were calculated as the product of the corrected POC concentration reported above and the ${ }^{210} \mathrm{~Pb}$-derived sediment mass accu-

b CF-model derived accumulation rates

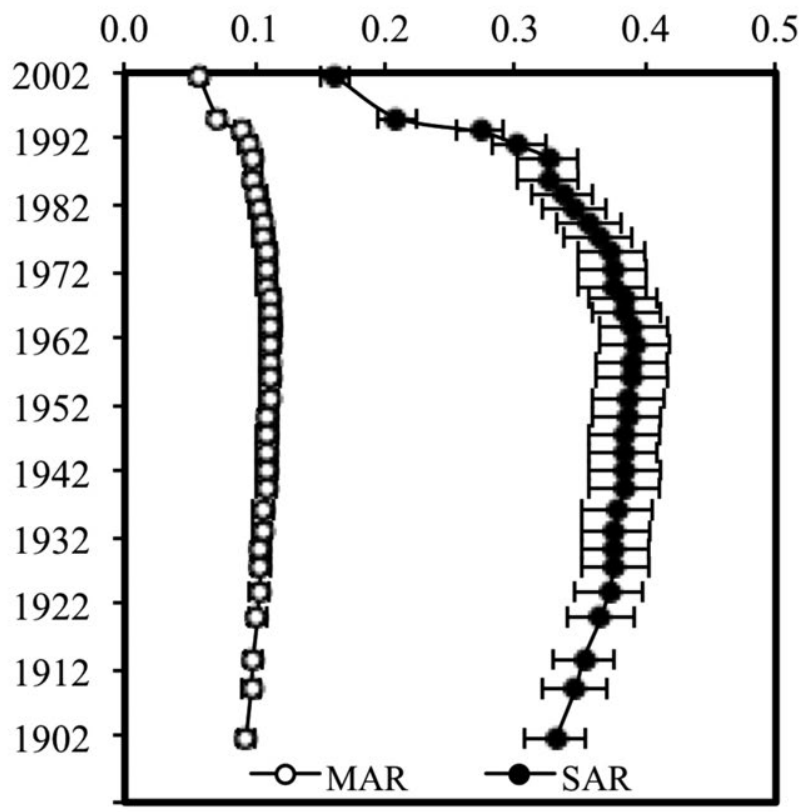

Fig. 4. a) Excess ${ }^{210} \mathrm{~Pb}$ activities in the core. b) ${ }^{210} \mathrm{~Pb}$-derived sediment accumulation rate (SAR, in $\mathrm{cm}^{-1}$ year ${ }^{-1}$ and mass accumulation rates (MAR, in $\mathrm{g} \mathrm{cm}^{-2}$ year $^{-1}$ ). 
mulation rate $\left(\mathrm{g} \mathrm{cm}^{-2} \mathrm{year}^{-1}\right)$ for each layer of the core. Thus, the POC flux varied between 14.9 and $25.6 \mathrm{~g} \mathrm{~m}^{-2}$ year ${ }^{-1}$ for segment $A$, and between 20.1 and $35.3 \mathrm{~g} \mathrm{~m}^{-2}$ year ${ }^{-1}$ for segment B. Since annual rates of POC accumulation are related to the trophic condition of the lake, but also vary considerably according to the size and the sedimentation rate of the lake, small lakes might have higher POC accumulation rates than large ones, either due to their generally higher ratio of lake watershed area to lake volume (Mulholland and Elwood, 1982; Downing et al., 2008) or because they have higher sediment fluxes.

\section{DISCUSSION}

Cole et al. (2007) suggested that small lakes contribute to carbon sequestration by storing carbon in the sediments that reflects not only the lake productivity but also the sedimentary accumulation rates and preservation capacity. Our findings show that Lake Alchichica deposits, buries, sequesters and preserves amounts of POC that are large compared with those in other lakes of similar or even higher trophic status, considering that - in contrast to Lake Alchichica, whose POC is mostly autochthonous - most lakes receive a large amount of allochthonous POC from

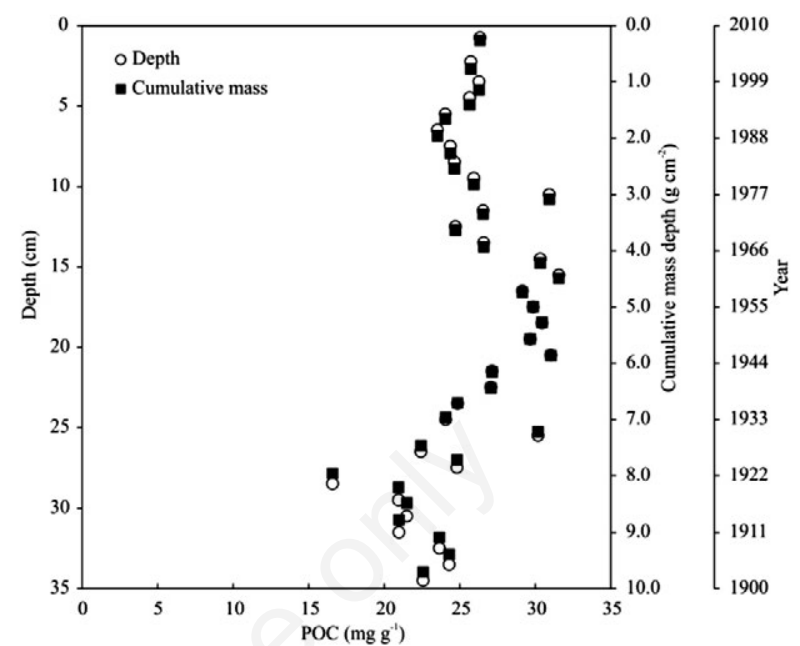

Fig. 5. POC concentration profile in the Lake Alchichica core as a function of depth (in $\mathrm{cm}$ ) and of mass depth (cumulative weight, in $\mathrm{g} \mathrm{cm}^{-2}$ ).

Tab. 2. Modeled particulate organic carbon fluxes for the Alchichica sediment core.

\begin{tabular}{|c|c|c|c|c|c|}
\hline $\begin{array}{l}\text { Depth } \\
\text { (cm) }\end{array}$ & $\begin{array}{c}\text { POC }^{*} \\
\left(\mathrm{mg} \mathrm{g}^{-1} \text { d.w. }\right)\end{array}$ & $\begin{array}{c}\text { POC-modeled }^{\circ} \\
\text { ( } \mathrm{mg} \mathrm{g}^{-1} \text { d.w.) }\end{array}$ & $\begin{array}{l}\text { POC-lost } \\
\left(\mathrm{mg} \mathrm{g}^{-1} \text { d.w. }\right)\end{array}$ & $\begin{array}{l}\text { POC-corrected } \\
\text { (mg g } \\
\text {-1 d.w.) }\end{array}$ & $\begin{array}{l}\text { POC flux } \\
\left(\mathrm{g} \mathrm{m}^{-2} \mathrm{y}^{-1}\right)\end{array}$ \\
\hline \multicolumn{6}{|c|}{ Segment A } \\
\hline $0.0-1.5$ & 26.3 & 30.6 & -4.2 & 26.3 & 14.9 \\
\hline $1.5-3.0$ & 25.7 & 26.4 & 0.0 & 25.7 & 18.3 \\
\hline $3.0-4.0$ & 26.3 & 25.5 & 0.8 & 27.1 & 24.0 \\
\hline $4.0-5.0$ & 25.7 & 24.8 & 1.5 & 27.2 & 25.4 \\
\hline $5.0-6.0$ & 24.0 & 24.3 & 2.1 & 26.1 & 25.4 \\
\hline $6.0-7.0$ & 23.5 & 23.5 & 2.8 & 26.3 & 25.6 \\
\hline \multicolumn{6}{|c|}{ Segment B } \\
\hline $14.0-15.0$ & 30.3 & 24.6 & -0.3 & 30.3 & 33.3 \\
\hline $15.0-16.0$ & 31.6 & 24.4 & 0.0 & 31.6 & 34.8 \\
\hline $16.0-17.0$ & 29.2 & 24.1 & 0.2 & 29.4 & 32.6 \\
\hline $17.0-18.0$ & 29.9 & 23.9 & 0.5 & 30.4 & 33.5 \\
\hline $18.0-19.0$ & 30.4 & 23.6 & 0.8 & 31.2 & 34.2 \\
\hline $19.0-20.0$ & 29.7 & 23.4 & 1.0 & 30.7 & 33.7 \\
\hline $20.0-21.0$ & 31.0 & 23.1 & 1.3 & 32.3 & 35.3 \\
\hline $21.0-22.0$ & 27.1 & 22.9 & 1.5 & 28.7 & 31.2 \\
\hline $22.0-23.0$ & 27.1 & 22.6 & 1.7 & 28.8 & 31.2 \\
\hline $23.0-24.0$ & 24.9 & 22.4 & 1.9 & 26.8 & 28.8 \\
\hline $24.0-25.0$ & 24.1 & 22.3 & 2.1 & 26.2 & 28.2 \\
\hline $25.0-26.0$ & 30.2 & 22.1 & 2.3 & 32.5 & 34.7 \\
\hline $26.0-27.0$ & 22.4 & 21.9 & 2.5 & 25.0 & 26.2 \\
\hline $27.0-28.0$ & 24.8 & 21.7 & 2.7 & 27.5 & 28.6 \\
\hline $28.0-29.0$ & 16.6 & 21.5 & 2.9 & 19.4 & 20.1 \\
\hline $29.0-30.0$ & 21.0 & 21.4 & 3.0 & 24.0 & 24.6 \\
\hline $30.0-31.0$ & 21.5 & 21.2 & 3.2 & 24.7 & 25.1 \\
\hline $31.0-32.0$ & 21.0 & 21.0 & 3.4 & 24.4 & 24.4 \\
\hline
\end{tabular}

POC, particulate organic carbon; : measured POC concentrations; ${ }^{\circ}$ modelled POC concentrations according to Middelburg (1989): * estimated POC concentration lost through mineralization according to Zimmerman and Canuel (2002); 'sestimated POC concentrations before mineralization; ${ }^{\wedge}$ estimated from corrected POC concentrations and mass accumulation rates; d.w., dry weight. 
the watershed. The concentration of recently sedimented POC in Lake Alchichica is similar or higher (range: 12-60 $\mathrm{mg} \mathrm{C} \mathrm{g}^{-1}$ d.w. or $1.2-6.0 \%$ OC) to that in some other oligotrophic (e.g., Lake Laja 1.2-9.9\%; Urrutia et al., 2002) or even mesotrophic (e.g., Lake Kinneret 1.5-3.9\% OC; Sobek et al., 2011; Delta do Paraiba do Sul 0.1-4.5\%; Sobrinho da Silva et al., 2011) and eutrophic (e.g., Lake Metztitlán 0.5-2.6\% POC; Fernández, 2004; Lake San Pablo 4 2.4\%; Gunkel, 2003) water bodies. However, most of the oligotrophic lakes displaying large concentrations of sedimented POC receive high inputs of dissolved (or colloidal) alochthonous organic matter - or even freshly fallen tree leaves - from the watershed, which flocculate and settle onto the sediment (von Wachenfeldt and Tranvik, 2008). By contrast, the POC found in the sediment traps close $(3 \mathrm{~m})$ to the bottom of Lake Alchichica is mostly ( $>90 \%)$ autochthonous, consisting of phytoplankton cells and amorphous organic matter (Oseguera et al., 2011).

A combination of three interrelated characteristics most likely explains the high POC concentrations in Lake Alchichica sediments: i) the larger size of the dominant phytoplankton; ii) the anoxic hypolimnion; and iii) the scarce benthic biota. Although there are only few studies available on this topic, these factors are expected to be shared by deep, tropical lakes, which, like Alchichica, turn out to be warm monomictic according to Lewis (1996). Diverse factors diminish or prevent POC oxidation in the water column, favoring its accumulation in the sediment. Among these are anoxia, the refractory nature of some organic compounds, and the amount of carbon deposited
(Betts and Holland, 1991; Hedges et al., 1999). The POC accumulation rate in the sediment depends on the amount of autochthonous and alochthonous supplies, the oxidation rate of the organic matter (respiratory rate), the lake morphometry, and its trophic status (Mullholland and Elwood, 1982). Velasco et al. (2011) found that as a consequence of the dominance of the phytoplankton biomass by $C$. alchichicana, the phytoplankton fluxes were higher than those measured in other oligotrophic and mesotrophic lakes. An important proportion of the phytoplankton biomass in Lake Alchichica is rapidly exported below the thermocline (sedimentation velocity $=4 \mathrm{~m}^{\text {day }}{ }^{-1}$; Alcocer et al., 2008), favouring its accumulation in the sediments. The relatively cold $\left(\sim 14.5^{\circ} \mathrm{C}\right.$ all year round) and anoxic (half of the year) deep waters promote the accumulation of sedimented POC. Adame et al. (2008) calculated the amount of oxygen required to oxidize the phytoplanktonic biomass (transformed to POC) that reaches the hypolimnion of Lake Alchichica from the onset of stratification onwards, showing a high DO deficit (i.e., it would require an extra 2560 to 2930 tonnes of DO to totally oxidize the phytoplanktonic POC reaching the hypolimnion). These data explained the prompt development of hypolimnetic anoxia. Anoxia in the bottom layer starts as early as April, and the hypolimnion becomes completely anoxic in June. Once the hypolimnion becomes anoxic, the remineralization of organic matter (sediment respiration) slows down, leading to its accumulation (Schultz and Zabel, 2006).

The rapid development and long duration of anoxic hypolimnetic conditions are common features of tropical,

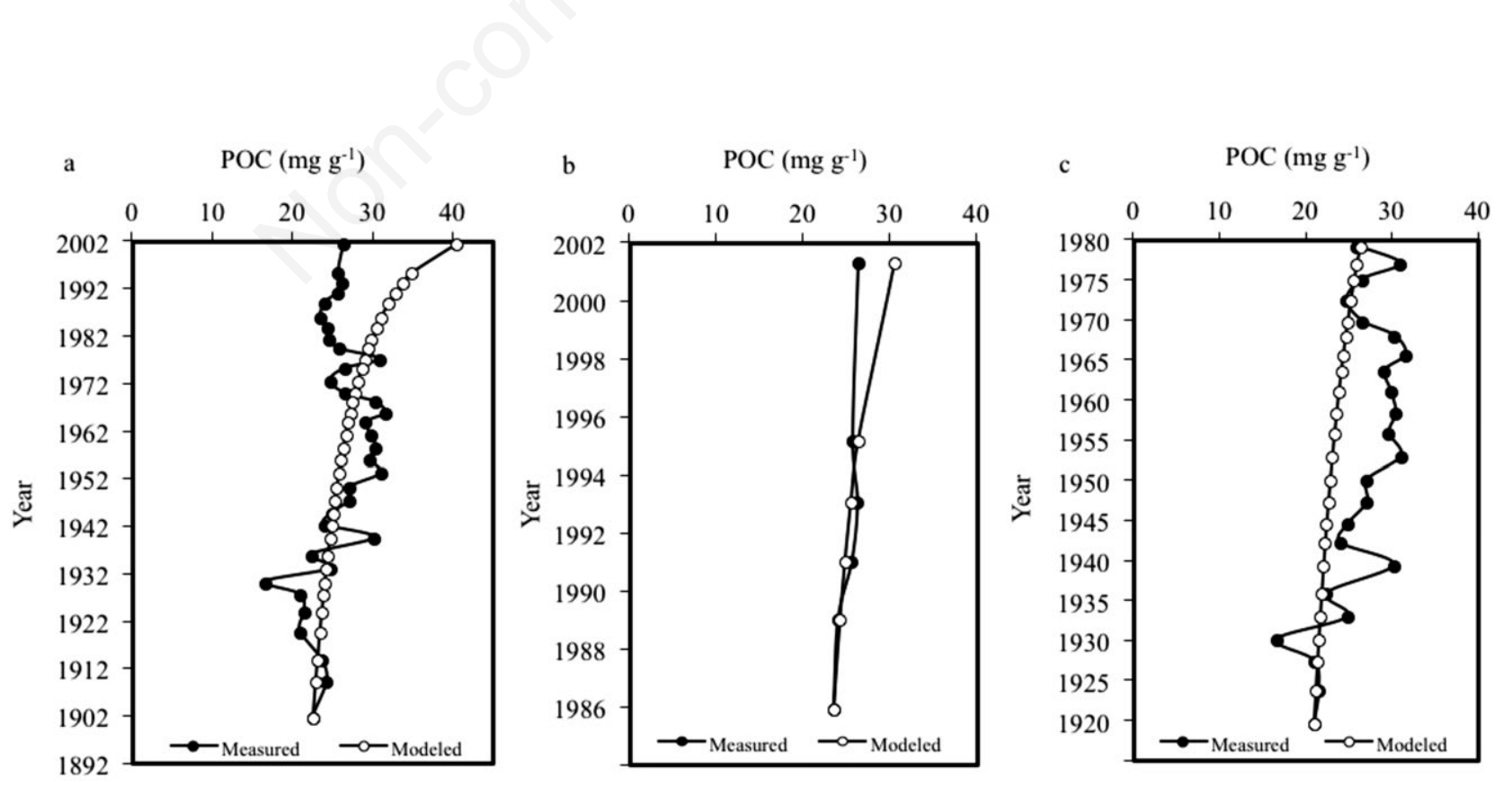

Fig. 6. Time-dependent particulate organic carbon concentrations in Alchichica sediment core [measured (•) vs modeled (o)]. a) The whole sediment core, from 1902-2001. b) Segment A, for the period 1986-2001. c) Segment B, for the period 1920-1979. See text for further explanation. 
deep, warm-monomictic lakes, even those with low primary productivity. Mixing coincides with the hemispheric winter and, in contrast to temperate lakes, the mixing season may be as short as one month or six weeks (Lewis, 1996). The combination of a lower oxygen inventory in the hypolimnion (higher hypolimnetic temperatures) and higher oxygen consumption rates (higher microbial activity) leads to a substantially lower expected duration of the persistence of oxygen in the hypolimnion (Lewis, 2002). Deep benthic fauna in Lake Alchichica is rare, most probably as a result of the extended anoxic period (8-9 months). Two species have been found: one ostracod (Candona patzcuaro) and one chironomid (Chironomus stigmaterus). The ostracod has been found at low densities $\left(285 \pm 271 \mathrm{org} \mathrm{m}^{-2}\right)$ and remains inactive most of the year (8-9 months) (Hernández et al., 2010). The chironomid occurs only during the oxygenated period (3-4 months), and also in low numbers ( $90 \pm 252$ org $\mathrm{m}^{-2}$ ). Consequently, it is to be expected that only small quantities of POC are incorporated into the detrital benthic food chain. Both factors - the anoxic conditions and the very limited occurrence of benthic fauna - suggest that most POC reaching the lake bottom is buried and thus sequestered. The estimated POC concentrations recorded in the sediment core (16.6 to $31.6 \mathrm{mg} \mathrm{g}^{-1}$ d.w.) are of the same order of magnitude as those found in other oligotrophic lakes, such as some of the English lakes [e.g., Wastwater $=58.6 \mathrm{mg} \mathrm{g}^{-1}$; Thirlmere $=88.4 \mathrm{mg}$ $\mathrm{g}^{-1}$; Buttermere $=57.3 \mathrm{mg} \mathrm{g}^{-1}$; Ennerdale Water $=58.3 \mathrm{mg}$ $\mathrm{g}^{-1}$; Crummock Water $=43.2 \mathrm{mg} \mathrm{g}^{-1}$ (Gorham et al., 1974)]. They also fell within the range of POC concentrations observed in the surface sediments (12-60 mg C $\mathrm{g}^{-1}$ d.w.), indicating high POC preservation in the sedimentary column; this is corroborated by the low values of POC loss by diagenesis that were observed downcore $(<11 \%$ in section A and $<25 \%$ in section $\mathrm{B})$. The estimated $\mathrm{POC}$ concentrations in segment $\mathrm{B}$ were higher than in segment A, perhaps as a result of the following: i) an increased delivery of organic matter to the sediment, either by enhanced primary productivity in the lake or by sediment focusing from the redistribution of shallowwater (littoral) sediment OC to deeper parts of the lake; or ii) enhanced organic matter preservation due either to decreased dissolved oxygen concentrations in the bottom water (Lee, 1992); and/or higher sediment mass accumulation rates (SAR; Henrichs and Reeburgh, 1987). High SAR may be partly controlled by increased primary productivity and might also favor the preservation of organic matter by reducing the exposure of POC to dissolved oxygen in the water column, and can therefore contribute to higher concentrations of carbon in sediments.

The SAR values found at Lake Alchichica are comparable with those found in other oligotrophic lakes such as South Lake in the Adirondack Mountains $\left(0.2 \mathrm{~cm}_{\text {year }}{ }^{-1}\right.$;
David and Mitchell, 1985), ten lakes in the sub-Arctic region of Quebec (0.075-0.30 cm year ${ }^{-1}$, Lucotte et al., 1995), and three deep basin lakes ( $>70 \mathrm{~m}$ depth) in New Zealand (0.14-0.23 $\mathrm{cm}$ year $^{-1}$; Trolle et al., 2008). They also fell within the typical range of SAR values estimated by Webb and Webb (1988) for small lakes $(0.02-0.3 \mathrm{~cm}$ year $\left.{ }^{-1}\right)$. According to the ${ }^{210} \mathrm{~Pb}$-derived chronology of the MAR and SAR, the Alchichica core recorded a decreasing sediment supply since the early 1970 s, which might explain the smaller POC concentrations found in segment A. The POC fluxes estimated for Lake Alchichica fall within the range reported by Mulholland and Elwood (1982) for POC burial rates in small $\left(<100 \mathrm{~km}^{2}\right)$, oligotrophic and meso-eutrophic lakes (3-128 and 11-198 g $\mathrm{m}^{-2}$ year $^{-1}$, respectively), and are slightly lower than the mean burial rate estimated for small lakes $\left(72 \mathrm{~g} \mathrm{~m}^{-2}\right.$ year $^{-1}$ ) by Dean and Gorham (1998). The comparatively higher POC fluxes estimated for the oldest segment of the core (before the 1980s) could be a consequence of a higher primary production in the past; in addition, the lower POC fluxes in the most recent segment of the core, might also be related to the reduction in the fluxes of organic detritus from a former littoral zone (i.e., sediment focusing) characterized by the presence of macrophytes and benthic algae that are no longer present owing to the lowering of the water level of Lake Alchichica. This lowering is documented by aerial photographs taken in 1974 and 1995 (Alcocer and Escobar-Briones, 2007) and photographs taken during fieldwork in 1979 (Caballero et al., 2003).

Previous studies elsewhere (Lyons et al., 1994; Tranvik et al., 2009; Yu et al., 2009) have already discussed the importance of saline lake sediments in preserving organic matter, although their preservation mechanisms are still poorly understood. High rates of organic matter preservation in sediments have been related to high productivity in the surface waters, high sedimentation rates, stratification of the lake water column leading to low or zero dissolved oxygen in the bottom water (Hedges and Keil, 1995), and the predominance of clays in the sediment in which organic matter is sorbed (Yu et al., 2009). All these conditions are met in Lake Alchichica and, therefore, might explain the high amount of POC buried in the sedimentary column, which accounts for an inventory of $2.5 \mathrm{~kg} \mathrm{~m}^{-2}$ accumulated during the past 104 years (35 cm depth). POC fluxes estimated from the Alchichica sediment core are comparable to values reported for small oligotrophic lakes with low accumulation rates (generally $<40 \mathrm{~g} \mathrm{C} \mathrm{m}^{-2}$ year $^{-1}$ ) and for eutrophic lakes with higher accumulation rates, usually $>30 \mathrm{~g} \mathrm{C} \mathrm{m}^{-2}$ year $^{-1}$ and up to $>100 \mathrm{~g} \mathrm{C} \mathrm{m}^{-2}$ year $^{-1}$ (Mulholland and Elwood, 1982). In this way, Lake Alchichica acts as a carbon sink in the region, and other similar tropical lakes should be re-evaluated with regard to the role they might play in the global carbon cycle. 


\section{CONCLUSIONS}

Estimated POC concentrations in the surficial sediments of the deep zone of Lake Alchichica average $25 \pm 12 \mathrm{mg}$ POC $\mathrm{g}^{-1}$ d.w. (12-60 mg POC $\mathrm{g}^{-1} \mathrm{~d}$.w.). These values are higher than those reported from other lakes of equivalent or even higher trophic status. In contrast to other oligotrophic lakes, which typically receive large inputs of allochthonous POC from the watershed as mentioned by Tranvik et al. (2009), the estimated POC in the sediments of Alchichica is autochthonous, deriving from the phytoplankton sedimentation. On an annual basis, higher estimated POC accumulation in the sediments occurs during the early stratification period, as a result of the sedimentation of the winter diatom bloom that had occurred during the circulation period. The ${ }^{210} \mathrm{~Pb}$-derived geochronology obtained from the core showed variable sediment accumulation rates during the past $\sim 104.2 \pm 6.8$ years. These accumulation rates range from 0.16 to $0.39 \mathrm{~cm} \mathrm{year}^{-1}$, with the lower values recorded in the uppermost layers of the core, starting in the early 1970s. The POC concentrations found in the most recent layers of the core (younger than 1980) showed lower values than those found in the previous decades, although the POC concentration depth distribution observed in both periods recorded in the core is mostly the result of post-depositional diagenesis. The retrospective analysis of POC input to the sediments indicated that the POC fluxes estimated for the last 20 years (14.9 to $25.6 \mathrm{~g} \mathrm{~m}^{-2}$ year $^{-1}$ ) are diminishing in comparison with the previous 84 years recorded in the core (20.1 to $35.3 \mathrm{~g} \mathrm{~m}^{-2}$ year $^{-1}$ ), most probably owing to the reduced transport of littoral organic debris promoted by the current lower water levels of the lake. Taking into account that the maximum degradative loss estimated for the POC profile along the core was $25 \%$, this study concludes that the deep zone of Lake Alchichica has a high capacity to preserve the POC buried in the sediments. The large amount of POC sequestered in the sediments can be explained by the rapid development of hypolimnetic anoxia and its long duration, the scarcity of benthic fauna, and a relatively large amount of POC derived from the export of large phytoplankton.

Our findings modify the perception that tropical, oligotrophic lakes are unimportant for carbon deposition, burial and sequestration, and the data demonstrate the role these lakes play in regional carbon balances. We conclude that, independently of the lake's trophic status (i.e., the magnitude of primary production), the phytoplankton size could be relevant for carbon capture and export processes. This study of Lake Alchichica suggests that deep, tropical lakes that develop anoxic hypolimnia over extended periods, may tend to accumulate and eventually sequester the POC deposited, and therefore may play an important role in regional carbon balances.

\section{ACKNOWLEDGMENTS}

This project was financially supported by Consejo Nacional de Ciencia y Tecnología (CONACyT) project 103332 and INFRA2013-01/204818, and Dirección General de Asuntos del Personal Académico de la UNAM (DGAPA) PAPIIT projects IN221009, IN215512, and IN105009. Acknowledgments are due to R. Lecuanda (ICML) and G.T. Rowe (TAMUG) for technical advice, to L. Peralta, C. Ramírez-Jáuregui, G. Ramírez-Reséndiz, P. Mellado-Vázquez and S. Bojórquez-Sánchez for technical assistance in the field and laboratory, and to Ann Grant for language improvement.

\section{REFERENCES}

Adame MF, Alcocer J, Escobar E, 2008. Size-fractionated phytoplankton biomass and its implications for the dynamics of an oligotrophic tropical lake. Freshwater Biol. 53:22-31.

Alcocer J, Bernal-Brooks FW, 2010. Limnology in Mexico. Hydrobiologia 644:15-68.

Alcocer J, Escobar-Briones E, 2007. On the ecology of Caecidotea williamsi Escobar-Briones and Alcocer (Crustacea: Isopoda: Asellidae) from Alchichica saline lake, Central Mexico. Hydrobiologia 576:103-109.

Alcocer J, Escobar E, Oseguera L, 2008. [Acoplamiento pelágico bentónico: respuesta de la zona béntica profunda a la sedimentación del florecimiento invernal de diatomeas en el lago oligotrófico Alchichica, Puebla, México]. [Article in Spanish]. Hidrobiologica 18:115-122.

Alcocer J, López D, Oseguera L, 2007. [Dinámica del carbono particulado en un lago tropical profundo, p. 239-247]. En: B. Hernández de la Torre and G. Gaxiola Carbono (eds.), [Ecosistemas Acuáticos de México].[Book in Spanish]. Instituto Nacional de Ecología y CICESE, México.

Alcocer J, Lugo A, Escobar E, Sánchez MR, Vilaclara G, 2000. Water column stratification and its implications in the tropical warm monomictic Lake Alchichica, Puebla, Mexico. Int. Ver. Theor. Angew. 27:3166-3169.

Arar E, Collins G, 1997. In vitro determination of Chl $a$ and pheophytin $a$ in marine and freshwater algae by fluorescence. US Environmental Protection Agency Cincinnati, Method 445.0.

Ardiles V, Alcocer J, Vilaclara G, Oseguera L, Velasco L, 2011. Diatom fluxes in a tropical, oligotrophic lake dominated by large-sized phytoplankton. Hydrobiologia 679:77-90.

Bertoni R, Callieri C, 1981. Underwater transmittance as a tool in the study of spatial distribution of particulate organic matter. Int. Ver. Theor. Angew. 21:120-124.

Betts JN, Holland HD, 1991. The oxygen content of ocean bottom waters, the burial efficiency of organic carbon, and the regulation of atmospheric oxygen. Global Planet. Change 5:5-18.

Billett DSM, Lampitt RS, Rice AL, Mantoura RFC, 1983. Seasonal sedimentation of phytoplankton to the deep-sea benthos. Nature 302:520-522.

Bloesch J, Uehlinger U, 1990. Epilimnetic carbon flux and turnover of different particle size classes in oligomesotrophic Lake Lucerne, Switzerland. Arch. Hydrobiol. 118:403-419. 
Burdige DJ, 2007. Preservation of organic matter in marine sediments: controls, mechanisms, and an imbalance in sediment organic carbon budgets? Chem. Rev. 107:467-485.

Caballero M, Vilaclara G, Rodríguez A, Juárez D, 2003. Shortterm climatic change in lake sediments from Lake Alchichica, Oriental, Mexico. Geofis. Int. 42:529-537.

Callieri C, 1997. Sedimentation and aggregate dynamics in Lake Maggiore, a large, deep lake in Northern Italy. Mem. Ist. Ital. Idrobiol. 56:37-50.

Callieri C, Bertoni R, Contesini M, 1986. Settling rates of particulate matter in lago di Mergozzo (Northern, Italy). Mem. Ist. Ital. Idrobiol. 44:147-164.

Chang J, Shiah F, Gong G, Chiang KP, 2003. Cross-shelf variation in carbon-to-chlorophyll a ratios in the East China Sea, summer 1998. Deep Sea Res. II 50:1237-1247.

Cho BC, Azam F, 1990. Biogeochemical significance of bacterial biomass in the ocean's euphotic zone. Mar. Ecol. Prog. Ser. 63:253-259.

Cole JJ, Prairie YT, Caraco NF, McDowell WH, Tranvik LJ, Striegl RG, Duarte CM, Kortelainen P, Downing JA, Middelburg JJ, Melack J, 2007. Plumbing the global carbon cycle: integrating inland waters into the terrestrial carbon budget. Ecosystems 10:172-185.

David MB, Mitchell MJ, 1985. Sulfur constituents and cycling $\mathrm{m}$ waters, seston, and sediments of an oligotrophic lake. Limnol. Oceanogr. 30:1196-1207.

Dean WE, Gorham E, 1998. Magnitude and significance of carbon burial in lakes, reservoirs, and peatlands. Geology 26:535-538.

De La Rocha C, Passow U, 2007. Factors influencing the sinking of POC and the efficiency of the biological carbon pump. Deep Sea Res. II 54:639-658.

Downing JA, Cole JJ, Middelburg JJ, Striegl RG, Duarte CM, Kortelainen P, Prairie YT, Laube KA, 2008. Sediment organic carbon burial in agriculturally eutrophic impoundments over the last century. Global Biogeochem. Cycles 22:GB1018.

El Rayis OA, 1985. Re-assessment of the titration method for determination of organic carbon in recent sediments. Rapport de la Commission Internationale de la Mer Méditerranee 29:45-47.

Fernández L, 2004. [Evaluación de plaguicidas organoclorados en el sistema lacustre de Metztitlán, Hidalgo]. [Thesis in Spanish]. Universidad Autónoma Metropolitana, Ciudad de Mexico.

Filonov A, Tereshchenko I, Alcocer J, 2006. Dynamic response to mountain breeze circulation in Alchichica, a crater lake in Mexico. Geophys. Res. Lett. 33:L07404.

Gorham E, Lund JWG, Sanger JE, Dean WE Jr, 1974. Some relationships between algal standing crop, water chemistry, and sediment chemistry in the English Lakes. Limnol. Oceanogr. 19:601-617.

Gunkel G, 2003. [Limnología de un Lago Tropical de Alta Montaña, en Ecuador: características de los sedimentos y tasa de sedimentación]. [Article in Spanish]. Rev. Biol. Trop. 51:381-390.

Hamilton TF, Smith JD, 1986. Improved alpha-energy resolution for the determination of polonium isotopes by alpha-spectrometry. Appl. Radiat. Isotopes 37:628-630.

Hedges JI, Hu FS, Devol AH, Hartnett HE, Tsamakis E, Keil
RG, 1999. Sedimentary organic matter preservation: an assessment and speculative synthesis. Am. J. Sci. 299: 529-555.

Hedges JI, Keil RG, 1995. Sedimentary organic matter preservation: an assessment and speculative synthesis. Mar. Chem. 49:81-115.

Henrichs SM, Reeburgh WS, 1987. Anaerobic mineralization of marine sediment organic matter: rates and the role of anaerobic processes in the ocean carbon economy. Geomicrobiol. J. 5:191-237.

Hernández MC, Escobar E, Alcocer J, 2010. [Ensamble de crustáceos bentónicos en un lago salino tropical]. [Article in Spanish]. Rev. Mex. Biodiv. 81:133-140.

Honjo S, Manganini SJ, Cole JJ, 1982. Sedimentation of biogenic matter in the deep ocean. Deep Sea Res. A 29:609-625.

Koegler FC, 1967. Geotechnical properties of recent marine sediments from the Arabian Sea and the Baltic Sea, p. 170-176. In: A.F. Richards (ed.) Geotechnique. University of Illinois Press.

Lampert W, Sommer U, 1997. Limnoecology. The ecology of lakes and streams. Oxford University Press, Oxford: 382 pp.

Lee C, 1992. Controls on organic carbon preservation: the use of stratified water bodies to compare intrinsic rates of decomposition in oxic and anoxic systems. Geochim. Cosmochim. Acta 56:3323-3335.

Legendre L, 1999. Environmental fate of biogenic carbon in lakes. Japan J. Limnol. 60:1-10.

Lewis WM Jr, 1996. Tropical lakes: how latitude makes a difference, pp 43-64. In: F. Schiemer and K.T. Boland (eds.), Perspectives in tropical limnology. SPB Academic Publ., Amsterdam.

Lewis WM, 2002. Causes for the high frequency of nitrogen limitation in tropical lakes. Int. Ver. Theor. Angew. 28: 210-213.

Lewis WM, 2010. Biogeochemistry of tropical lakes. Int. Ver. Theor. Angew. 30:1595-1603.

Loring DH, Rantala RTT, 1992. Geochemical analyses of marine sediments and suspended particulate matter. Fisheries and Marine Services, Technical Report 700: 58 pp.

Lucotte M, Mucci A, Hillaire-Marcel C, Pichet P, Grondin A, 1995. Anthropogenic mercury enrichment in remote lakes of northern Québec (Canada). Water Air Soil Poll. 80:467-476.

Lugo A, Alcocer J, Sánchez MR, Escobar E, Macek M, 2000. Temporal and spatial variation of bacterioplankton abundance in a tropical, warm-monomictic, saline lake: Alchichica, Puebla, Mexico. Int. Ver. Theor. Angew. 27: 2968-2971.

Lyons WB, Hines ME, Last WB, Lent RM, 1994. Sulfate reduction rates in salt lakes of varying chemistries: Implications for organic matter accumulation, pp 13-20. In: R. Renault and W. Last (eds.), Sedimentology and geochemistry of modern and ancient saline lakes. SEPM Special Publication No. 50, Tulsa.

Middelburg JJ, 1989. A simple rate model for organic matter decomposition in marine sediments. Geochim. Cosmochim. Ac. 53:1577-1581.

Mulholland P, Elwood J, 1982. The role of lake and reservoir sediments as sinks in the perturbed global carbon cycle. Tellus 34:490-499.

Oliva MG, Alcocer J, Lugo A, Peralta L, Sánchez MR, 2001. 
Phytoplankton dynamics in a deep, tropical hyposaline lake. Hydrobiologia 466:299-306.

Oliva MG, Lugo A, Alcocer J, Cantoral-Uriza E, 2006. Cyclotella alchichicana sp. nov. from a saline lake. Diatom Res. 21:81-89.

Oliva MG, Lugo A, Alcocer J, Cantoral-Uriza E, 2008. Morphological study of Cyclotella choctawhatcheeana Prasad (Stephanodiscaceae) from a saline Mexican lake. Saline Syst. 4:17.

Oseguera LA, Alcocer J, Escobar E, 2010. Seston flux in a tropical saline lake. Int. Ver. Theor. Angew. 30:1477-1481.

Oseguera LA, Alcocer J, Vilaclara G, 2011. Relative importance of dust inputs and aquatic biological production as sources of lake sediments in an oligotrophic lake in a semi-arid area. Earth Surf. Proc. Land. 36:419-426.

Pilskaln CH, 2004. Seasonal and interannual particle export in an African rift valley lake: a 5 year record from Lake Malawi, Southern East Africa. Limnol. Oceanogr. 49:964-977.

Punning JM, Terassma J, Koff T, Alliksaar T, 2003. Seasonal fluxes of particulate matter in a small closed lake in Northern Estonia. Water Air Soil Poll. 149:77-92.

Ramos-Higuera E, Alcocer J, Ortega E, Camacho A, 2008. [Nitrógeno: elemento limitante para el crecimiento fitoplanctónico en un lago oligotrófico tropical]. [Article in Spanish]. Hidrobiologica 1:105-113.

Robbins JA, 1978. Geochemical and geophysical applications of radioactive lead isotopes, p. 285-393. In: J.O. Nriagu (ed.), Biochemistry of lead. Elsevier, Amsterdam.

Sánchez-Cabeza JA, Masqué P, Ani-Ragolta I, 1998. ${ }^{210} \mathrm{~Pb}$ and ${ }^{210} \mathrm{Po}$ analysis in sediments and soils by microwave acid digestion. J. Radioanal. Nucl. Ch. 227:19-22.

Sánchez-Cabeza JA, Ruiz-Fernández AC, 2012. ${ }^{210} \mathrm{~Pb}$ sediment radiochronology: an integrated formulation and classification of dating models. Geochim. Cosmochim. Ac. 82:183-200.

Schell WR, Nevissi A, 1983. Sedimentation in lakes and reservoirs, p. 163-176. In: IAEA, Guidebook on Nuclear Techniques in Hydrology, Technical Reports Series N. 91.

Schultz H, Zabel M, 2006. Marine geochemistry. Springer Verlag: $537 \mathrm{pp}$.

Selig U, Michalik M, Hübener T, 2006. Assessing P status and trophic level of two lakes by speciation of particulate phosphorus forms. J. Limnol. 65:17-26.

Simon M, Graossart HP, Schweitzer B, Ploug H, 2002. Microbial ecology of aggregates in aquatic ecosystems. Aquat. Microb. Ecol. 28:175-211.

Sobek S, Zurbrügg R, Ostrovsky I, 2011. The burial efficiency of organic carbon in the sediments of Lake Kinneret. Aquat. Sci. 73:355-364.

Sobrinho da Silva F, Mattos L, Sabadini E, Mattos V, Carlos M,
Mendonça J, 2011. [Biopolímeros, Carbono e Enxofre Totais Associados à Atividade Bacteriana dos Sedimentos Superficiais do Delta do Paraíba do Sul, RJ-Brasil]. [Article in Portuguese]. Anuário do Instituto de Geociências UFRJ 34:33-45.

Takahashi K, Fujitani N, Yanada M, Maita Y, 2000. Long-term biogenic particle fluxes in the Bering Sea and the central subarctic Pacific Ocean, 1990-1995. Deep Sea Res. A 47:1723-1759.

Tranvik LJ, Downing JA, Cotner JB, Loiselle SA, Striegl RG, Ballatore TJ, Dillon PJ, Finlay K, Fortino K, Knoll LB, Kortelainen PL, Kuster T, Larsen S, Laurion I, Leech DM, McCallister SL, McKnight DM, Melack JM, Overholt E, Porter JA, Prairie Y, Renwick JA, Roland F, Sherman BS, Schindler DW, Sobek S, Tremblay A, Vanni MJ, Verschoor AM, Wachenfeldt Ev, Weyhenmeyer GA, 2009. Lakes and reservoirs as regulators of carbon cycling and climate. Limnol. Oceanogr. 54: 2298-2314.

Trolle D, Hamilton DP, Hendy C, Pilditch C, 2008. Sediment and nutrient accumulation rates in sediments of twelve New Zealand lakes: influence of lake morphology, catchment characteristics and trophic state. Mar. Freshwater Res. 59:1067-1078

Urrutia R, Yevenes M, Barra R, 2002. [Determinación de los niveles basales de metales traza en sedimentos de tres lagos andinos de Chile: Lagos Chungará, Laja y Castor]. [Article in Spanish]. Bol. Soc. Chil. Quím. 47:457-467.

Velasco L, Ardiles V, Vilaclara G, Alcocer J, 2011. [Sedimentación de las principales especies de fitoplancton en el Lago Alchichica, México, p. 161-173]. In: F.R. Gío Argaez and M.T.L Rosales Hoz. (eds.), [Interacciones en el Planeta Tierra]. [Book in Spanish]. ICML, UNAM. México.

Vilaclara G, Chávez M, Lugo A, González H, Gaytán M, 1993. Comparative description of crater-lakes basic chemistry in Puebla State, Mexico. Int. Ver. Theor. Angew. 25:435-440.

von Wachenfeldt E, Tranvik LJ, 2008. Sedimentation in boreal lakes - the role of flocculation of allochthonous dissolved organic matter in the water column. Ecosystems 11:803-814.

Webb R, Webb III T, 1988. Rates of sediment accumulation in pollen cores from small lakes and mires of Eastern North America. Quaternary Res. 30:284-297.

Yu B, Dong H, Jiang H, Lv G, Eberl D, Li S, Kim J, 2009. The role of clay minerals in the preservation of organic matter in sediments of Qinghai Lake, NW China. Clay. Clay Miner. 572:213-226.

Zimmerman AR, Canuel EA, 2002. Sediment geochemical records of eutrophication in the mesohaline Chesapeake Bay. Limnol. Oceanogr. 47:1084-1093. 